\title{
Energy partitioning of pregnant and lactating rabbit fed combination of concentrate and stylosanthes hamata hay \\ ${ }^{1}$ Tsavkar, D. T*., ${ }^{2}$ Latu, M. Y., ${ }^{1}$ Olutunmogun, A. K., ${ }^{1}$ Barje, P. P. and ${ }^{1}$ Iyeghe- \\ Erakpotobor, G. T. \\ ${ }^{I}$ National Animal Production Research Institute, Ahmadu Bello University, Shika, Zaria, Kaduna State, Nigeria. \\ ${ }^{2}$ Department of Animal Science, Ahmadu Bello University, Zaria, Kaduna State, Nigeria, \\ Abstract \\ *Corresponding author: torver2018@gmail.com; torver2015@yahoo.com
}

The study was carried out to examine energy partitioning of pregnant and lactating rabbit offered levels of concentrate and Stylosanthes hamata hay to ascertain whether it meets their high reproductive and nutritional requirement. Forty-eight nulliparous crossbred does (New Zealand White $x$ California and California $x$ Chinchilla breeds) of eight months old were allocated to four dietary treatments in a completely randomised design. During gestation, $150 \mathrm{~g} /$ doe/day concentrate and Stylosanthes hamata hay combinations (30:120g, 60:90g, 90:60g and 120:30g) was offered while $350 \mathrm{~g} /$ doe/day concentrate and Stylosanthes hamata hay combinations (70:280g, 140:210g, 210:140g and 280:70g) was offered during lactation. Estimations of digestible energy during pregnancy and lactation were carried out and reference data were used to calculate for $D E_{\text {req, }} D E_{m,} D E_{f, s} D E_{\text {macc, }}$ Balance $D E$ and $D E_{\text {red }} L W^{0.75}$. Results obtained showed non-significant $(P>0.05)$ difference among 90:60 and 120:30\% concentrate and Stylosanthes hamata hay combinations in terms of $D M_{\text {intake, }} D E_{\text {intake, }} D E_{\text {req, }} D E_{f g}$, $D E_{\text {macc }}$ Balance $D E$ and $D E_{\text {red }} / L W^{0.75}$, but were significantly $(P<0.05)$ higher than 30:120 and 60:90\% concentrate and Stylosanthes hamata hay combinations. Rabbit in the $4^{\text {th }}$ week of pregnancy had significantly $(P<0.05)$ higher $D E_{\text {intake, }} D E_{\text {req, }} D E_{f,}, D E_{\text {macc, }}$ Balance $D E$ and $D E_{\text {red }} / L W^{0.75}$ than does in the $2^{\text {nd }}$ week of pregnancy. During lactation, all parameters showed non-significant $(P>0.05)$ difference. Therefore, the diet combinations were sufficient to provide adequate digestible energy for the physiological needs of does during pregnancy and lactation.

Keywords: Rabbit does, Energy Partitioning, Pregnancy, Concentrate, Stylosanthes hamata hay.

\section{Introduction}

The success of animal production and reproduction is determined by several interactive factors like genetic make-up of the animal, nutrition, temperature, photoperiod and stress. Among these factors, nutrition has a great influence on the ability to achieve both production and reproduction goals (Iyeghe-Erakpotobor and Ashworth, 2003). Energy is the largest proportion of nutrients in a compounded animal diet and also the highest cost of production (Soenke et al., 2005). Feed energy concentration is the main factor responsible for ingestion of dry matter and ostensibly other nutrients such as protein, amino acid and vitamins which contributes to the animal production and total wellbeing, that is to say animals will eat to meet their energy needs and consequently other nutrients alongside energy (Xiccato and Trocino, 2010). Energy is not a nutrient parse, but a quality associated with the nutrient content of feed stuffs and mixed diets (Noblet, 2007). It has been reported that reproduction and growth requires about 300 - 500kcal DE $/ \mathrm{kg}$ more than maintenance requirement in rabbit due to high energy 


\section{Energy partitioning of pregnant and lactating rabbit}

demand for pregnancy and lactation which usually leads to negative energy balance (Xiccato and Trocino, 2010). The knowledge of energy utilisation and physiological state of rabbits is essential for formulating diets that will meet the nutrients requirement and support intensive breeding rhythms (Toschi et al., 2004). It is therefore, important to estimate precisely the energy values of feed for adapting feed supply to energy requirement of animals (Noblet, 2007). In view of the above, this experiment was designed to examine the energy partitioning of pregnant and lactating rabbit does offered levels of concentrate and Stylosanthes hamata hay to ascertain whether it meets their high reproductive and nutritional requirement.

\section{Materials and methods Experimental site}

The experiment was conducted at the Unit of Swine and Rabbit Research Programme of the National Animal Production Research Institute (NAPRI), Shika, Nigeria, located in the northern Guinea savannah ecological zone. The area lies between latitude $10^{\circ} 11^{\prime} \mathrm{N}$ and longitude $7^{\circ} 8^{\prime} \mathrm{E}$, and 650 meters above sea level (Ovimaps, 2014). The area receives an annual rainfall of $1100 \mathrm{~mm}$, which is spread from April to October. The mean minimum and maximum temperature ranges from 12 $-28^{\circ} \mathrm{C}$ during the cold (harmattan) season and $20-36^{\circ} \mathrm{C}$ in the hot season. Relative humidity during the rainy season is about $75 \%$ and $21 \%$ during the dry season (IAR, 2014).

\section{Experimental animals and management}

Forty-eight nulliparous crossbred does (New Zealand White x California and California x Chinchilla breeds) of eight months old were allotted to four dietary treatments in a completely randomised design. After allotting the does to each dietary treatments, does were then introduced to bucks in their cages in a mating ratio of 1 buck: 6 does. After a successful mating was confirmed, by the buck thrusting forward and falling by its side, the does were then returned to their cages. Mating was carried out between 8:00 - 9:00am. The diets containing concentrate and Stylosanthes hamata hay combinations of $30: 120 \mathrm{~g}, 60: 90 \mathrm{~g}, 90: 60 \mathrm{~g}, 120: 30 \mathrm{~g}$ was fed during pregnancy and $70: 280 \mathrm{~g}$, $140: 210 \mathrm{~g}, 210: 140 \mathrm{~g}, 280: 70 \mathrm{~g}$ was fed during lactation. The Stylosanthes hamata was harvested from the pasture farm of the Feed and Nutrition Research Programme Farm, dried at room temperature and chopped before feeding while the concentrate diet was formulated and contained crude protein of $22 \%$ and metabolisable energy of $2,600 \mathrm{ME} / \mathrm{Kg}$ (Table 1).

Table 1: Composition of concentrate diets fed to pregnant and lactating rabbit

\begin{tabular}{ll}
\hline Ingredients & Composition (\%) \\
\hline Maize & 39.24 \\
Groundnut & 42.26 \\
Maize offal & 15.00 \\
Bone & 3.00 \\
Salt & 0.25 \\
Vitamin/minerals premix & 0.25 \\
Total & $\mathbf{1 0 0 . 0 0}$ \\
\hline
\end{tabular}

*Vitamin/mineral premix content per kilogram ration: vit. A 1251 IU, vit. D3 2750 IU, vit. E 151 IU, vit. K 0.002 g, vit. B2 0.006 g, nicotinic acid $0.035 \mathrm{~g}$, calcium D-pantothenate $0.01 \mathrm{mg}$, vit. B6 $0.0035 \mathrm{~g}$, vit. B12 $0.02 \mathrm{~g}$, folic acid $0.001 \mathrm{~g}$, biotin $0.0005 \mathrm{~g}$, vit. C $0.025 \mathrm{~g}$, cholin chloride $0.39 \mathrm{~g}$, zinc bacitracin $0.02 \mathrm{~g}$, methionine $0.2 \mathrm{~g}$, avatec (lasolocid) $0.09 \mathrm{~g}$, manganese $0.1 \mathrm{~g}$, iron $0.05 \mathrm{~g}$, zinc $0.04 \mathrm{~g}$, copper $0.002 \mathrm{~g}$, iodine $0.00153 \mathrm{~g}$, cobalt $0.000225 \mathrm{~g}$, selenium $0.0001 \mathrm{~g}$. 


\section{Tsavkar, Latu, Olutunmogun, Barje and Iyeghe-Erakpotobor}

Estimations of digestible energy during pregnancy and lactation was carried out and reference data were used in the calculation of digestible energy requirement $\left(\mathrm{DE}_{\text {req }}\right)$ and digestible energy required for foetal $\left(\mathrm{DE}_{\mathrm{fg}}\right)$ and digestible energy required for maintenance $\left(\mathrm{DE}_{\mathrm{m}}\right)$ according to Parigi Bini and Xiccato (1998). Does were housed individually in metal cages housed in a well-ventilated building with large open windows. Pregnant does were offered a total of $150 \mathrm{~g}$ feed/doe/day while lactating does were offered $350 \mathrm{~g}$ feed/doe/day. Water was given ad libitum. Flat bottom earthen feeders with rims were used for feeding the rabbits to avoid wastage. The experiment lasted for four months.

\section{Data collection and statistical analysis}

Data were collected and analyzed for live weight, digestible energy (intake, requirement, maintenance, foetal growth, balance and metabolic weight) on pregnancy and lactation and interaction between pregnancy phase and with the dietary treatments using the General Linear Model Procedure of SAS (1987). Orthogonal pair wise difference was used to separate significant means. Interaction effects between level of dietary treatment and stage of pregnancy were dropped because it was not significant. Below is the mathematical models used for the analysis:
Pregnancy:

$\mathrm{Y}_{\mathrm{ijk}}=\mu+\square_{\mathrm{i}}+\mathrm{S}_{\mathrm{j}}+\left(\square_{\mathrm{i}} * \mathrm{~S}_{\mathrm{j}}\right)+\square_{\mathrm{ijk}}$

Where;

$\mathrm{Y}_{\mathrm{ijk}}=$ observation on the $\mathrm{i}^{\text {th }}$ treatment in the

$j^{\text {th }}$ stage of pregnancy,

$\mu=$ overall mean,

$\square_{i}=$ fixed effect of treatment

$\mathrm{S}_{\mathrm{j}}=$ fixed effect of stage of pregnancy,

$\left(\square_{\mathrm{i}} * \mathrm{~S}_{\mathrm{j}}\right)=$ interaction between treatment and stage of pregnancy

$\square_{\mathrm{ijk}}=$ random error with mean $=0$ and $\sigma^{2}$

\section{Lactation:}

$\mathrm{Y}_{\mathrm{ij}}=\mu+\square_{\mathrm{i}}+\square_{\mathrm{ij}}$

Where;

$\mathrm{Y}_{\mathrm{ij}}=$ observation on the $\mathrm{i}^{\text {th }}$ treatment,

$\mu=$ overall mean,

$\square_{\mathrm{i}}=$ fixed effect of dietary treatment,

$\square_{\mathrm{ij}}=$ random error

\section{Results and discussion}

The energy partitioning of pregnant rabbit offered levels of concentrate and Stylosanthes hamata hay combinations is shown in Table 2. There were nonsignificant $(\mathrm{P}>0.05)$ differences between 90:60 and 120:30 concentrate and Stylosanthes hamata hay combinations in terms of $\mathrm{DM}_{\text {intake, }}, \mathrm{DE}_{\text {intake, }} \mathrm{DE}_{\text {req, }}, \mathrm{DE}_{\mathrm{fg}}, \mathrm{DE}_{\text {macc, }}$ Balance $\mathrm{DE}$ and $\mathrm{DE}_{\mathrm{req}} / \mathrm{LW}^{0.75}$, although these were significantly $(\mathrm{P}>0.05)$ higher than 30:120 and 60:90 concentrate and Stylosanthes hamata hay combinations, which were similar.

Table 2: Energy partitioning of pregnant rabbit does offered levels of concentrate and Stylosanthes hamata hay combinations

\begin{tabular}{|c|c|c|c|c|c|c|}
\hline \multirow[b]{2}{*}{ Parameters } & \multicolumn{6}{|c|}{ Concentrates and Stylosanthes hamata hay combinations (g) } \\
\hline & $30: 120$ & $60: 90$ & $90: 60$ & $120: 30$ & SEM & P-value \\
\hline Live weight (kg) & $1.99^{\mathrm{b}}$ & $2.04^{\mathrm{a}}$ & $1.99^{\mathrm{b}}$ & $2.18^{\mathrm{a}}$ & 0.02 & 0.0305 \\
\hline $\mathrm{DM}_{\text {intake }}(\mathrm{g} / \mathrm{d})$ & $88.62^{\mathrm{b}}$ & $110.09^{\mathrm{b}}$ & $152.54^{\mathrm{a}}$ & $159.20^{\mathrm{a}}$ & 3.28 & 0.0001 \\
\hline $\mathrm{DE}_{\text {intake }}(\mathrm{kj} / \mathrm{d})$ & $1739.24^{\mathrm{b}}$ & $2180.70^{\mathrm{b}}$ & $3006.63^{\mathrm{a}}$ & $3173.38^{\mathrm{a}}$ & 14.45 & 0.0001 \\
\hline $\mathrm{DE}_{\text {req }}(\mathrm{kj} / \mathrm{d})$ & $1238.73^{\mathrm{c}}$ & $1392.20^{\mathrm{b}}$ & $1631.98^{a}$ & $1750.28^{a}$ & 19.03 & 0.0001 \\
\hline $\mathrm{DE}_{\mathrm{m}}(\mathrm{kj} / \mathrm{d})$ & $699.56^{\mathrm{b}}$ & $716.19^{\mathrm{a}}$ & $699.92^{b}$ & $766.53^{\mathrm{a}}$ & 7.80 & 0.0322 \\
\hline $\mathrm{DE}_{\mathrm{fg}}(\mathrm{kj} / \mathrm{d})$ & $539.16^{\mathrm{b}}$ & $676.02^{\mathrm{b}}$ & $932.05^{\mathrm{a}}$ & $983.75^{\mathrm{a}}$ & 18.75 & 0.0001 \\
\hline $\mathrm{DE}_{\text {macc }}(\mathrm{kj} / \mathrm{d})$ & $852.23^{b}$ & $1068.54^{\mathrm{b}}$ & $1473.25^{\mathrm{a}}$ & $1554.96^{\mathrm{a}}$ & 29.64 & 0.0001 \\
\hline BalanceDE (kj/d) & $500.51^{b}$ & $788.49^{b}$ & $1374.65^{\mathrm{a}}$ & $1423.10^{\mathrm{a}}$ & 43.76 & 0.0001 \\
\hline $\mathrm{DE}_{\mathrm{req}} / \mathrm{LW}^{0.75}(\mathrm{~d})$ & $622.99^{\mathrm{b}}$ & $689.91^{\mathrm{b}}$ & $823.33^{\mathrm{a}}$ & $804.80^{\mathrm{a}}$ & 10.88 & 0.0001 \\
\hline
\end{tabular}




\section{Energy partitioning of pregnant and lactating rabbit}

The result showed that there was increase in dry matter intake $\left(\mathrm{DM}_{\text {intake }}\right)$, digestible energy intake $\left(\mathrm{DE}_{\text {intake }}\right)$, digestible energy requirement $\left(\mathrm{DE}_{\mathrm{req}}\right)$, digestible energy for maintenance $\left(\mathrm{DE}_{\mathrm{m}}\right)$, digestible energy for foetal growth $\left(\mathrm{DE}_{\mathrm{fg}}\right)$, digestible energy for maternal accretion $\left(\mathrm{DE}_{\text {macc }}\right)$, balance of digestible energy $\left(\mathrm{DE}_{\mathrm{bal}}\right)$ and digestible energy requirement per metabolic weight per day $\left(\mathrm{DE}_{\mathrm{req}} / \mathrm{LW}^{0.75} /\right.$ day) as the amount of concentrate increased and Stylosanthes hamata decreased. The pregnant rabbits were in positive DE utilisation for all the parameters considered, indicative that all the combinations were adequate to satisfy the requirements for pregnancy in rabbits probably due to higher feed intake, high crude digestibility as reported by Bamikole and Ezenwa (1999) and high availability of nutrients from the Stylosanthes hamata hay and the concentrate which could be a sign of good performance of the combinations in terms of energy as reported by IyegheErakpotobor et al. (2006). The positive DE utilisation for all the parameters considered is also an indication that the Stylosanthes hamata hay is high in non-lignified materials (Cheeke, et al., 1986). He also reported that while digestibility of protein, fibre and energy of tropical grasses is very low in rabbits, many of the tropical legumes are as digestible as temperate forages.

Table 3 shows the effect of stage of pregnancy on energy partitioning of rabbit does offered levels of concentrate and Stylosanthes hamata hay combinations. Rabbit does in the $4^{\text {th }}$ week of pregnancy had significantly $(\mathrm{P}<0.05)$ higher $\mathrm{DE}$ intake, requirement, foetal growth, maternal accretion, balance and requirement per metabolic weight than does in the $2^{\text {nd }}$ week of pregnancy although DE for maintenance was similar for does in the $2^{\text {nd }}$ and $4^{\text {th }}$ weeks of pregnancy. The increase in the dry matter and digestible energy intake in the fourth week of pregnancy can be attributed to a need to meet the high energy requirements for proper foetal growth and development and for maternal needs. This is due to the fact that in the second week of pregnancy, energy need was more for cell and organ differentiation which was not energy demanding as compared to the last period of pregnancy that involved growth of the foetus, maternal tissue accretion and maintenance. This agrees with the earlier report of Iyeghe-Erakpotobor et al. (2009), Latu et al. (2017) and Olutunmogun et al. (2017) that nutrient requirement increases thereby leading to high nutrient requirement in the fourth week of pregnancy. The positive digestible energy balance observed in both stages of pregnancy indicates the possibilities of maintaining pregnant rabbits on combinations of concentrate and Stylosanthes hamata hay without adverse effect on reproduction (IyegheErakpotobor et al., 2009 and Olutunmogun etal., 2017).

Table 4 shows the energy partitioning of lactating rabbit does offered concentrate and Stylosanthes hamata hay combinations. There was non-significant $(\mathrm{P}>0.05)$ difference in all the parameters considered. The rabbit does were in positive balance of DE utilisation for all the combinations of concentrate and Stylosanthes hamata hay. 
Table 3: Effect of Stage of Pregnancy on Energy partitioning of Pregnant Rabbit Does offered levels of concentrate and stylosanthes hamata hay combinations

\begin{tabular}{lllll}
\hline & \multicolumn{4}{l}{ Stage of pregnancy (week) } \\
\cline { 2 - 5 } Parameters & 2 & 4 & SEM & P value \\
\hline Live weight $(\mathrm{kg})$ & 2.03 & 2.07 & 0.02 & 0.3928 \\
$\mathrm{DM}_{\text {intake }}(\mathrm{g} / \mathrm{d})$ & $116.07^{\mathrm{b}}$ & $139.16^{\mathrm{a}}$ & 3.28 & 0.0014 \\
$\mathrm{DE}_{\text {intake }}(\mathrm{kj} / \mathrm{d})$ & $2301.01^{\mathrm{b}}$ & $2748.96^{\mathrm{a}}$ & 14.45 & 0.0008 \\
$\mathrm{DE}_{\text {req }}(\mathrm{kj} / \mathrm{d})$ & $1426.95^{\mathrm{b}}$ & $1579.54^{\mathrm{a}}$ & 19.03 & 0.0003 \\
$\mathrm{DE}_{\mathrm{m}}(\mathrm{kj} / \mathrm{d})$ & 713.64 & 724.46 & 7.80 & 0.3403 \\
$\mathrm{DE}$ & $713.31^{\mathrm{b}}(\mathrm{kj} / \mathrm{d})$ & $852.18^{\mathrm{a}}$ & 18.75 & 0.0008 \\
$\mathrm{DE}$ & $1127.50^{\mathrm{b}}$ & $1346.99^{\mathrm{a}}$ & 29.64 & 0.0008 \\
$\mathrm{BalanceDE}_{\mathrm{b}}$ & $874.06^{\mathrm{b}}$ & $1169.31^{\mathrm{a}}$ & 43.76 & 0.0021 \\
$\mathrm{DE}$ & $\left.705.81^{\mathrm{b}} / \mathrm{LW}\right)$ & $764.70^{\mathrm{a}}$ & 10.88 & 0.0119 \\
\hline
\end{tabular}

Means within rows with different superscripts are significant $(\mathrm{p}<0.05)$ different. DM intake $=$ dry matter intake, DE req $=$ Digestible energy

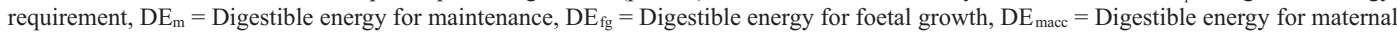
accretion, balanceDE $=$ balance of digestible energy, $\mathrm{DE}_{\mathrm{req}} / \mathrm{LW} 0.75 /$ day $=$ digestible energy requirement per metabolic weight per day.

Table 4: Energy partitioning by lactating does fed different concentrate and stylosanthes hamata hay combinations

\begin{tabular}{|c|c|c|c|c|c|c|}
\hline \multirow[b]{2}{*}{ Parameters } & \multicolumn{6}{|c|}{ Concentrates and Stylosanthes hamata hay combinations (g) } \\
\hline & 70:280 & $140: 210$ & 210:140 & 280:70 & SEM & P-value \\
\hline Live weight $(\mathrm{kg})$ & 2.60 & 3.16 & 2.62 & 2.60 & 0.23 & 0.7499 \\
\hline $\mathrm{DM}_{\text {intake }}(\mathrm{g} / \mathrm{d})$ & 124.74 & 123.13 & 127.03 & 116.36 & 3.54 & 0.8003 \\
\hline$D_{\text {intake }}(\mathrm{kj} / \mathrm{d})$ & 4822.82 & 4523.79 & 4555.64 & 3676.10 & 165.00 & 0.1890 \\
\hline TMP $(\mathrm{kg})$ & 3.21 & 3.36 & 3.34 & 3.41 & 0.09 & 0.8932 \\
\hline $\operatorname{TDE}_{\text {req }}(\mathrm{kj} / \mathrm{d})$ & 2920.96 & 3127.63 & 3004.94 & 3043.68 & 87.36 & 0.8586 \\
\hline $\mathrm{DE}_{\mathrm{m}}(\mathrm{kj} / \mathrm{d})$ & 880.78 & 993.81 & 883.87 & 878.47 & 49.85 & 0.7795 \\
\hline $\mathrm{DE}_{\text {milk }}(\mathrm{kj} / \mathrm{d})$ & 2040.18 & 2133.83 & 2121.08 & 2165.21 & 54.34 & 0.8951 \\
\hline $\mathrm{E}_{\text {milk }}$ & 1285.31 & 1344.31 & 1336.28 & 1364.08 & 34.23 & 0.8952 \\
\hline BalanceDE $(\mathrm{kj} / \mathrm{d})$ & 1901.86 & 1396.16 & 1550.73 & 632.42 & 213.27 & 0.3289 \\
\hline $\mathrm{LW}^{0.75}(\mathrm{~d})$ & 2.04 & 2.31 & 2.05 & 2.04 & 0.12 & 0.7785 \\
\hline $\mathrm{DE}_{\text {req }} / \mathrm{LW}^{0.75}(\mathrm{~d})$ & 1426.92 & 1426.36 & 1463.83 & 1505.22 & 36.06 & 0.8766 \\
\hline LWT3 (g) & 2.60 & 3.16 & 2.62 & 2.60 & 0.61 & 0.7499 \\
\hline $\mathrm{E}_{\text {milk }} \mathrm{FE}(\mathrm{kj} / \mathrm{d})$ & 809.74 & 846.91 & 841.86 & 859.37 & 57.05 & 0.8952 \\
\hline$E_{\text {milk }} B E(\mathrm{kj} / \mathrm{d})$ & 475.57 & 497.40 & 494.42 & 504.71 & 33.51 & 0.8951 \\
\hline $\mathrm{BE}_{\text {retain }}(\mathrm{kj} / \mathrm{d})$ & 609.70 & 637.69 & 633.88 & 647.06 & 42.96 & 0.8952 \\
\hline
\end{tabular}

$\mathrm{DM}_{\text {intake }}=$ Dry matter intake, TMP $=$ Total milk produced, TDE $\quad$ req $=$ Total digestible energy for requirement, DE $\mathrm{m}=$ Digestible energy for maintenance, $\mathrm{E}_{\text {milk }}=$ Energy in milk, balanceDE $=$ Digestible energy balance, $\mathrm{DF}_{\mathrm{feq}} \mathrm{LW}^{0.75} /$ day $=$ Digestible energy requirement per metabolic weight, LWT3 = Litter weight at 3 weeks, $E_{\text {milk }} F E=$ Energy in milk from feed, $E_{\text {milk }}$ BE = Energy in milk from body energy, BE $E_{\text {retain }}=$ Body $_{1}$ energy retain.

The positive result obtained in this study is contrary to the report of Xiccato and Trocino (2010) that body energy balance of lactating does is always negative and that great energy accretion through milk in lactating does is not fully compensated for by voluntary $\mathrm{DE}$ intake, especially in primiparous does. The positive result obtained in this study may be as a result of high energy content of the combinations as well as the high DM intake and high DE intake. The fact that lactating does on all combinations had positive balance of energy indicates that these combinations are suitable for lactation.

\section{Conclusion}

The study showed that the concentrate and stylosanthes hamata hay combinations were all sufficient to provide the necessary digestible energy to meet the physiological needs of rabbit does during pregnancy and 


\section{Energy partitioning of pregnant and lactating rabbit}

lactation phases. However, dietary combinations of $90: 60$ and 120:30 concentrate and Stylosanthes hamata hay offered during pregnancy had better performance than $30: 120$ and 60:90 combinations.

\section{Acknowledgement}

The authors wish to express their gratitude to the Executive Director, National Animal Production Research Institute, Shika-Zaria for releasing the facilities used for the study. The contributions of staff of the Rabbitry and Central Laboratory Unit, NAPRI are well appreciated.

\section{References}

Bamikole, M. A. and Ezenwa, I. 1999. Performance of rabbits on guinea grass and Verona stylo hays in the dry season and effect of concentrate supplementation. Journal of Feed Science Technology, 80(1): 67-73.

Cheeke, P. R., Grobner, M.A. and Patton, N. M. 1986. Fibre digestion and utilisation in rabbits. Journal of Applied Rabbits Research, 9(1):2530.

Institute of Agricultural Research, 2014. Metrological unit, weather report, Ahmadu BelloUniversity, Zaria.

Iyeghe-Erakpotobor, G. T. and Ashworth, C. J. 2003 . Relationship between live weight, liver weight and progesterone metabolism of Land Race X Large White and Meishan pigs in early pregnancy. ASSET Series A, 3(2):1-9.

Iyeghe-Erakpotobor, G. T., Aliyu, R. and Uguru, J. 2006. Evaluation of concentrate, grass a $\mathrm{n}$ d legume combinations on performance and nutrient digestibility of grower rabbits under tropical conditions. African Journal of Biotechnology, 4(20): 2004- 2006.

Iyeghe-Erakpotobor, G. T., Sekoni, A. A. and Esievo, L. O. 2009. Nutrient intakeand digestibility of rabbit does fed varying levels of concentrate and lablab during pregnancy.Nigerian Journal of Animal Production, 36(2): 275287.

Latu, M. Y., Olutunmogun, A. K., Barje, P. P. and Iyeghe-Erakpotobor, $\mathbf{G}$.

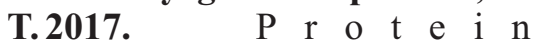
partitioning of pregnant and lactating rabbit does fed combination of concentrates and lablab hay. Journal of Animal Production Research, 29(1): 193 199.

Noblet, J. (2007). Net energy evaluation of feed and determination of net energy requirement for $\mathrm{p}$ i $\mathrm{g} \mathrm{s}$. Revista Brasileira de especial, Pp 277-284.

Olutunmogun, A. K., Latu, M. Y., Ereke, S., Iyeghe-Erakpotobor, G. T. and Barje, P.P. 2017 . Energy partitioning of pregnant and lactating rabbit does fed c o m b i n a t i o n s of concentrate and lablab hay. Journal of Animal Production Research, 29(2): 208-214.

Ovimaps, 2014. Ovilocation map; ovi earth imaginary. Dated July, 2017.

Parigi Bini, R. and Xiccato, G. 1998. Energy metabolism and requirement. In: C.de Blas., J. Wiseman (eds). The nutrition of the rabbit. CABI Publishing Wallingford, Oxen U K.P p 103- 131.

SAS. 1987. Statistical Analysis System, Computer Software, Version 6: 
Statistics SAS Institute Inc. Cary, NC 27513, NC 27513, USA.

Soenke, M., Jacob, A. and Ronald, O. B. 2005. Using net energy for diet formulation. Potential for the Canadian pig industry. Advances in pork production, 16: 119-129.

Toschi, I., Cesari, V., Rapitti, L., Bava, L., Grilli, G. and Castrovilli, G. 2004. Energy utilisation and partitioning of nulliparous rabbit does in the last third of pregnancy.

Proceedings of $8^{\text {th }}$ Word Rabbit Congress, Puebia Mexico, Pp 1002-1007.
Xiccato, G. 1996. Nutrition of lactating does. In: Lebas, F. (ed.) Proceeding of $6^{\text {th }}$ world rabbits congress, Toulouse. Association Française de cuniculture, Lampdes, France, 1:29-50.

Xiccato, G. and Trocino, A. 2010. Feed and energy intake in rabbit and consequences on $\mathrm{f}$ a $\mathrm{r} \mathrm{m}$ global efficiency. The $6^{\text {th }}$ International Conference on Rabbit Production in hot climate, Assiut, Egypt, 1-16.

Received: $29^{\text {th }}$ August, 2018 Accepted: $10^{\text {th }}$ February, 2019 